\title{
The Development of Academic Self-Management Inventory of Vocational High School Students
}

\author{
Bambang Dibyo Wiyono, Citra Fitri Kholidya \\ Universitas Negeri Surabaya \\ Surabaya, Indonesia \\ bambangwiyono@unesa.ac.id
}

\begin{abstract}
The purpose of this research is to develop academic self-management inventory of vocational high school students. The development of academic self-management inventory uses a development model developed by Borg \& Gall. This model is called research and development consisting of 10 development steps. The result of academic self-management inventory product through expert test, test and main field test obtained 50 items that meet the validity level of the construct. The result of the distribution of data is divided into three (3) categories, i.e. high, medium, and low academic self-management.
\end{abstract}

Keywords-development, academic self-management inventory

\section{INTRODUCTION}

Vocational education is one form of a formal education unit which is a continuation of basic education. Government Regulation of the Republic of Indonesia Number 29 of 1990 on Secondary Education article 1 paragraph 3 states that vocational secondary education is education at middle level prioritizing the development of students' ability to carry out certain types of work. In line with that, [1] suggests vocational education is an educational program that prepares individual learners to become a professional workforce.

Vocational education is organized in the form of Multiple System Education. [2] argues that Multiple System Education is essentially a form of professional skills education that synthesizes systematic and synchronous education programs in schools and skills acquisition programs obtained through direct working activities in the workplace, directed to achieve a certain level of professional expertise. Furthermore, according to [3], the management of teaching and learning activities in double system education, is based on several basic principles, namely: (1) there is a link between what is done in school and what is done in the partner institution as a whole series; (2) the practice of expertise in partner institutions is a whole, meaningful and full-fledged learning process to achieve graduate competency; (3) there is continuity of the learning process with the appropriate time in achieving the required level of competence; (4) oriented to the process in addition to oriented to the product in achieving the competence of graduates optimally

One of the determinants of academic success of vocational students is the ability of self-management. Mahoney \& Thoresen says self-management deals with awareness and skills to regulate the surroundings that affect individual behavior [4]. Independence and self-directed ability are important elements of self-management. [5] states that selfmanagement is a goal-oriented activity, based on selfregulation and self-discipline. Self-management aims to enable individuals to be self-sufficient, able to work or learn on their own initiative, carry out planned study and social activities, achieve optimal results, with positive feelings and avoid harmful inner experiences. [6] said there are several kinds of techniques that belong to the tactics of selfmanagement. The self-management tactics consist of: 1) selfmonitoring (self monitoring, self-monitoring); 2) self-reward; 3) stimulus control (stimulus control). This strategy emphasizes the responsibility of the counselee for his actions through the manipulation of external and internal events. The transfer of responsibility for self-conversion of the counselee is more in line with the counselee's self, since the individual is the person who knows best, is responsible and most likely to make changes to himself.

Based on the results of field studies at Vocational High School 5 Malang, it was found that Software Engineering (RPL) students largely decreased achievement when the level increase from class X to class XI. This is revealed when some students request individual counseling services related to their academic achievement. Some students also revealed that they find it difficult to divide the study time due to the dense schedule of theoretical lessons as well as practice. Some also revealed that experiencing relational barriers to feel uncomfortable while in his class. Some of these descriptions indicate low self-management abilities.

Counselee facing unique and varied challenges can have an impact on his personal, social, learning and career development. To help learners/counselors to be a generation that is ready to face the condition requires the support of various parties in synergy, including guidance and counseling teachers or counselors. Guidance and counseling in vocational schools are attempted to identify the needs of the personal, social, learning, and career areas that are essential activities in facing obstacles in achieving the potential achievement of each learner/counselee [7].

Counselors are required to know correctly the concepts, objectives and aspects of self-management that will be measured and its implications for everyday life, especially 
vocational students in accordance with the tasks of development. In dealing with the development of selfmanagement is required a tool to determine the level of selfmanagement students of vocational high school. The tool developed in the form of academic self-management inventory. Academic self-management inventory is one of the guidance instruments needed for guidance and counseling support activities. Student self-management inventory inventory of vocational high school is a list of statements specially designed to identify or identify the academic selfmanagement of vocational students. The academic selfmanagement inventory was chosen because it is easy to use counselor as one of the students' academic self-management instruments. The use of inventory is not judgmental, but merely collects data from statements, opinions of a person on the condition of a particular person's condition in general. With the understanding of students academic selfmanagement, counselors are expected to guide students to understand themselves properly.

Based on the above background, then the purpose of this study is to generate academic self-management inventory of vocational high school students whose level meets the standards of measuring instruments include the validity, reliability and norms.

\section{LITERATURE REVIEW}

Self-management is a recent popular term among contemporary behavioral experts. In [4] the term selfmanagement has several equivalent terms such as selfinstruction from Michenbaum, self-control of Mahoney \& Thoresen and self-direction from Watson \& Tharp. Selfmanagement is an important factor to recognize oneself that can support the achievement of optimal student development tasks.

Students are required to be able to manage themselves in line with its existence in puberty as a vocational student and as a person who was in negative times. In accordance with the operational definition that researchers adapt from the opinion of [5] that self-management is the activities undertaken by students and for themselves based on self-discipline and selfdiscipline with the characteristics of students carry out the process of independence that is working on their own initiative and carry out planning activities. Mahoney also argues that self-governance is a conscious and skilled effort to regulate circumstances with discipline [4]. Based on the above opinion, students' academic self-management can be described as follows:

a. Self-management related to learning styles and study habits

Learning is a process that results in behavioral change. Behavioral changes occur because of the exercise, experience and effort of the individual learning. The effort intended in this case is how the individual controls and directs the power from within and from outside to do learning behavior. The sequence of activities called learning involves various ways and steps. The way of each individual's learning is different.

b. Self-management in terms of time management

Students of SMK with various activities are always faced with how the student can manage the time. Time for some people is something very valuable, but for some people time is something that can be used to delay a job.

c. Self-management in connection with the utilization of facilities

Means is a tool supporting student learning activities. The better the students manage the available facilities, the easier it will be for students to do the learning activities. Learning facilities such as study rooms and learning tools. But not all students have adequate learning tools. Students can pursue learning tools that are absolutely necessary and which should be owned or not in accordance with the ability. Self-management related to the utilization of this facility include: the existence of study room, sociopsychological atmosphere, state of the stationery/practice, package/ module book, and laboratory practice.

d. Self-management related to barrier management Human life certainly cannot be separated from the problems of life. If the problem cannot be solved properly then it will be a barrier to the achievement of desired goals. Therefore, students as human beings also cannot be separated from the problems that accompany his activities, whether it is a problem related to himself and the problems associated with others.

Development of academic self-management instruments is in the form of inventory. According to [8] inventory can be developed in the form of statements that are adapted to the underlying concept or theory. In this case there is no right or wrong answer because inventory measures the tendency of certain characteristics of the individual.

\section{METHOD}

The development of this academic self-management inventory uses a development model developed by [9]. This model is called research and development consisting of 10 development steps: (1) research and information gathering; (2) planning; (3) develop product preliminary form; (4) preliminary field tests; (5) major product revisions; (6) main field tests; (7) revision of operational product; (8) operational field tests; (9) revision of the final product; and (10) dissemination and distribution. 


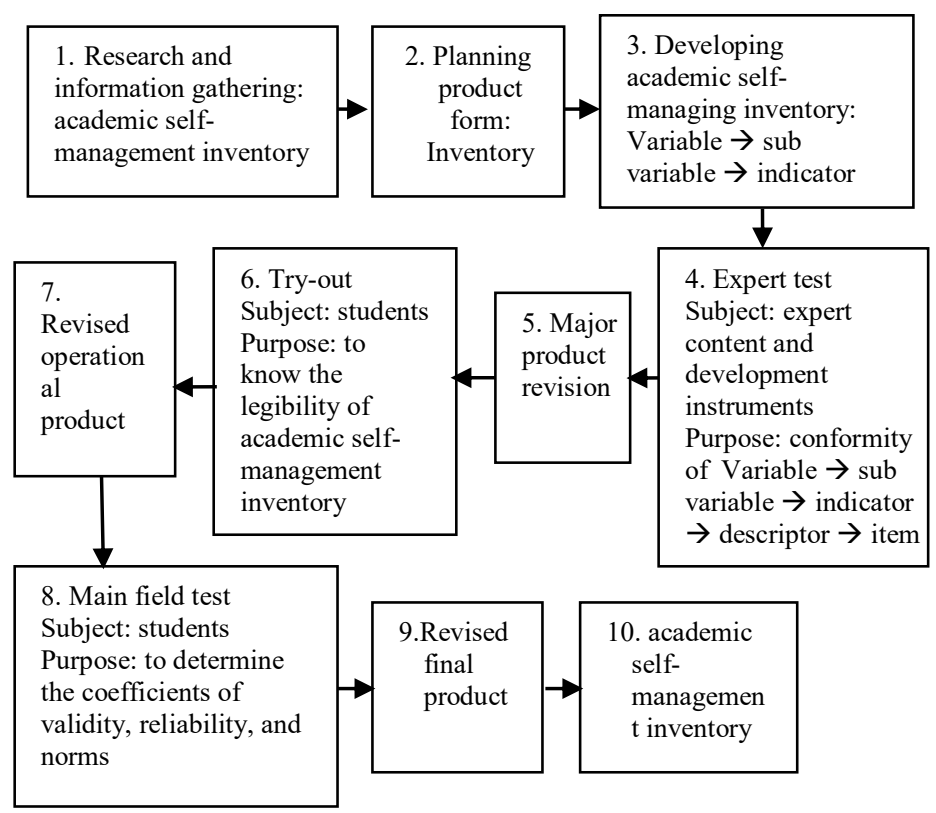

Fig. 1 Development Model (adaptation from

[9]

The main field test is the core activity of inventory testing on several student subjects that were sampled in this case the students of Vocational High School 5 Malang. The reason the developer took the research location in the school because in terms of development, the culture of the ability possessed and age is relatively the same. The sample in this research is determined by using purposive sampling technique. The rationale for the use of purposive samples is that the samples are intentionally drawn (non-randomly) because of the reasons for the nature, character, and state of the sample. Samples were taken $25 \%$ of all grade XI students or class samples.

\section{TABLE I SAMPLE}

\begin{tabular}{|c|c|c|}
\hline Population & Sample & The number of students \\
\hline Vocational High & XI RPL2 & 32 students \\
\cline { 2 - 3 } School 5 Malang & XI RPL4 & 36 students \\
\hline Total & & 68 students \\
\hline
\end{tabular}

Data of trial and field test result are divided into two types of data, they are qualitative data and quantitative data. Qualitative data obtained in the form of inputs, responses and suggestions from experts to repair items of inventory statement whether appropriate between sub variables and descriptors between indicators and statements. In addition, the developer receives feedback, feedback and suggestions from students for guidance on inventory workmanship or inventory readability.

Quantitative data is obtained in the form of figures from statistical test results to determine the frequency of student scores, the calculation of the coefficient of reliability, calculation of the coefficient of validity and norms of academic self-management inventory. Instruments used in data collection in the form of an assessment questionnaire which includes a questionnaire of expert judgment and a questionnaire of readability assessment.

The qualitative data are analyzed descriptively, while the quantitative data are analyzed using statistical formula to find the coefficient of validity, reliability and norm. For validity coefficient is calculated by using Product Moment Pearson correlation formula, for reliability using Cronbach Alpha formula or Alpha formula, while normality using formula of percentile formula. To calculate the coefficient of validity and reliability used calculations with the help of computer statistics program that is SPSS for Windows. The norm used in this study is the school norm. The form of this norm can be manifested in terms of percentile scores or rank percentiles. The percentile score shows the relative position of a student in his group in the sense that a few percent of the scores of other students are below him.

\section{RESULT}

The quantitative assessment of expert tests is performed by scoring on every aspect assessed by a score of 0 for the "Unsuitable" category, score of 1 for the "Less Match" category, score 2 for the "Appropriate" category. The results of the assessment of expert test quantitatively can be seen in the table as follows.

TABLE II RESULTS OF QUANTITATIVE EXPERT TEST

\begin{tabular}{|c|l|c|c|}
\hline \multirow{2}{*}{ No. } & \multicolumn{1}{|c|}{ Aspect of Assessment } & \multicolumn{2}{|c|}{ Total Score } \\
\cline { 3 - 4 } & & $\mathrm{A} 1$ & $\mathrm{~A} 2$ \\
\hline 1. & Conformity of indicators with sub-variables & 18 & 18 \\
\hline 2. & Compatibility descriptor with indicator & 58 & 58 \\
\hline 3. & Conformity item with descriptor & 172 & 168 \\
\hline
\end{tabular}

Experimental assessment results indicate that the conformity of indicators with sub-variables has a conformity score of 18 based on the assessment of (A1) and (A2). The conformity of the descriptor with the indicator has a conformity score of 58 based on the assessment of (A1) and 58 based on the assessment of (A2), while the conformity of the statement with the descriptor has a conformity score of 172 based on the assessment of (A1) and 168 based on the assessment of (A2).

Quantitative assessment of limited trials is conducted by providing answers to every aspect of the assessment: readability of students' understanding of the work instructions, understanding of words and language used in statements, sentence intentions, and alternative answers to academic selfmanagement inventory. The results of the trial assessment are limited quantitatively can be seen in the table as follows.

TABLE III RESULTS OF THE LIMITED LEGIBILITY TESTING ASSESSMENT

\begin{tabular}{|c|l|c|c|c|c|}
\hline \multirow{2}{*}{ No. } & \multirow{2}{*}{ Aspect of Assessment } & \multicolumn{4}{|c|}{ Answer } \\
\cline { 3 - 6 } & $\begin{array}{c}\text { Not } \\
\text { Underst } \\
\text { and }\end{array}$ & $\begin{array}{c}\text { Not } \\
\text { Completely } \\
\text { Understand }\end{array}$ & $\begin{array}{c}\text { Underst } \\
\text { and }\end{array}$ & $\begin{array}{c}\text { Very } \\
\text { Underst } \\
\text { and }\end{array}$ \\
\hline 1. & Instructions & $0 \%$ & $0 \%$ & $50 \%$ & $50 \%$ \\
\hline 2. & The language used in the item & $0 \%$ & $0 \%$ & $100 \%$ & $0 \%$ \\
\hline 3. & Sentences in the items & $0 \%$ & $0 \%$ & $60 \%$ & $40 \%$ \\
\hline 4. & Alternative answers provided & $0 \%$ & $0 \%$ & $100 \%$ & - \\
\hline
\end{tabular}


Based on the results of the readability assessment on a limited trial indicates that subjects in a limited trial understand the readability of the work instructions, the language used in the statement, the statements used in the statement, and the alternative answers to academic self-management inventory.

Qualitative assessment of limited trials is obtained in the form of feedback, responses, and suggestions from the subject of instructions on how to understand the words and languages used in statements, sentence intentions, and alternative answers to academic self-management inventory. The results of qualitative assessment of trials of 10 students show that:

1) The results of the assessment of the instructions on doing inventory of academic self-management are understood because the students have written the data themselves, can give a cross $(\mathrm{x})$ on the answer sheet and can replace the answers with others.

2) The assessment of the language used in the academic selfmanagement inventory statement is easy to understand because students have no difficulty with regard to language and its meaning.

3) The result of the assessment of the sentences used in the academic self-management inventory statement is clear because the student is able to understand the purpose of each sentence well.

4) The results of the assessment of alternative answers to academic self-management inventory are easy to understand because students can choose from 4 alternative answers: "Always", "Frequent", "Rarely", and "Never".

The presentation of quantitative data of field test results can be known through the validity, reliability and norm test. Calculation of validity using Product Moment Pearson correlation formula, calculation of reliability using Alpha formula while calculation of normality using percentile formula. Calculation of frequency distribution of scores of field test results of academic self-management inventory done by looking at the results of data processing SPSS 16.0.

Calculation of validity is done by comparing $r$ count with $r$ table at significance level $\mathrm{p} \leq 0.05$. If $\mathrm{r}$ arithmetic $\geq \mathrm{r}$ table and positive value then the item or question is declared valid. The table $r$ calculation is done with degree of freedom $(\mathrm{df})=\mathrm{n}-2$, in this case $n$ is the number of samples. In the number of sample $(\mathrm{n})=68$ and magnitude $\mathrm{df}=68-2=66 \mathrm{r}=0.2012$. Based on the results of SPSS 16.0 data processing shows that of 87 items of academic self-management inventory statement, 50 items declared valid with $\mathrm{r}$ arithmetic $\geq \mathrm{r}$ table with the level of significance $p \leq 0.05$, while 37 grains of statements declared invalid. The 37 grains of statements declared invalid (fall) are not used. The non-use of some statement items is invalid because the indicator is already represented with another statement item. After the invalid statement is omitted then the reliability test is done using the Alpha formula. The result of reliability calculation shows from 50 point statement obtained $\alpha=0.840$.

\section{DISCUSSION}

The results of the academic self-management inventory product after being revised through trials by the expert content and instrumentation lecturers as well as the main field test, of the 87 pointed exposures, obtained 50 items that meet the level of construct validity through expert test and calculation of the validity coefficient $r$ arithmetic $\geq r$ table with significance level $\mathrm{p} \leq 0.05$. As for 37 items of statement through validity calculation is declared invalid, then the statement based on the validity standard is declared or not used. Inventory statements have illustrated the academic self-management constructs of learning habits, time management, use of facilities and management of barriers. This is in accordance with the opinion of [5] that self-management is a goal-oriented activity, based on self-organization and self-discipline.

On points of valid and significant statements according to the validity of constructs filled through expert tests indicates that the items in the statement are theoretically in accordance with the constructs of self-management theory. This is in accordance with the statement [8] that inventory can be developed in the form of statements that are adapted to the underlying concept or theory. Furthermore, the statement item consists of positive statements and negative statements. This is in line with [10] who argues that inventory statements consist of two types, among others: positive statements about the object of attitude or favorable statement is a sentence that is positive, supportive and favorable to the attitude object as well as negative statements object attitude or unfavorable Namely a statement containing a sentence that does not support or counter.

After the product revision of academic self-management inventory development, 50 point statements have Alpha reliability coefficient level of 0.840 . This means that inventory statement items have a high level when tested on the same sample characteristics at different times. Academic self- selfmanagement inventory is said to have good reliability that has produce test scores are relatively consistent or unchanged. This is in line with Nunally's statement in [11] states a construct or variable is said to be reliable if it gives a cronbach alpha value $>0.6$.

Preparation of academic self-management inventory adjustment is structured using school norms with percentile norms or percentile scores. Percentiles are scores that are derived, expressed in terms of percentages. Thus, a percentile is a score that has been transformed in numerical form. The percentiles that are considered a rank in a group of 100, with a note that in the ranking usually people start counting from above, the best person in the group gets ranked one. On the other hand, percentiles were calculated from the bottom, so that the lower percentile, the worse the individual positions. The result of the distribution of data is divided into three (3) categories of high academic self, medium, and low. This corresponds to the percentile opinion is a score that has been transformed in the form of a percentage number [12].

The development of this academic self-management inventory supports the results of previous research. [13] produces a scale of self-control and self-management. [14] 
produces self-control inventory that meets good inventory criteria covering validity, reliability, and normality. Then, [15] research resulted in 21 self-management scale items with a reliability of 0.86 . [16] produces 37 items of academic selfmanagement scale of junior high school students with Alpha reliability coefficient level of 0.903 . Furthermore, [17] study resulted in self-control inventory of vocational high school students with Alpha reliability coefficient level of 0.733 .

Academic self-management inventory is one of the guidance instruments needed for guidance and counseling support activities. The revised academic self-management inventory can be used to identify or identify the academic selfmanagement of vocational students. With the understanding of academic self-management of vocational high school students, counselors are expected to guide students to understand themselves properly. This self-management academic inventory is self-reporting. Through the filling of inventory the individual can find his or her own position and be able to know how to manage his academic self as well as encourage individuals to improve their academic self-management based on the results they have earned.

Inventory has several advantages to know the individual characteristics. The advantage of using inventory is as an objective, economical, and efficient data collection tool about the individual's perception of himself about academic selfmanagement. While the weakness that can arise from the inventory of academic self-management that is less interesting inventory form and tabulation score that requires time and thoroughness. This weakness can be anticipated by making inventory design interesting. As for the tabulation of scores need to be created table of scores that can help in the calculation of student academic self-management score.

\section{CONCLUSION}

Based on research and development, obtained 50 items that meet the level of validity of the construct through expert test and calculation of the coefficient of validity $r$ arithmetic $\geq r$ table with a significance level of $\mathrm{p} \leq 0.05$ and Alpha reliability coefficient level of 0.840 . The result of the distribution of data is divided into three (3) categories of high academic selfmanagement, medium, and low.

\section{References}

[1] A. Djohar, Pendidikan Teknologi dan Kejuruan: Ilmu dan Aplikasi Pendidikan, Bandung: Pedagogiana Press, 2007.

[2] T. Permana, Pemahaman Konsep PSG dan Intensitas Bimbingan terhadap Kemampuan Membimbing Siswa PSG, INVOTEC 2005, 3 (7): 33-39.

[3] W. Nurharjadmo, Evaluasi Implementasi Kebijakan Pendidikan Sistem Ganda di Sekolah Kejuruan, Spirit Publik 2008, 4(2): 215-228.

[4] L. Fauzan, Pengubahan Kebiasaan Belajar Siswa SMA dengan Siasat Kelola Diri, Tesis tidak diterbitkan, Malang: Universitas Negeri Malang, 1992.

[5] A. Mappiare AT, Self-Management Sebagai Teknik Mengembangkan Kebiasaan Studi untuk Peningkatan Prestasi Akademik Mahasiswa, Malang: UBKMI IKIP Malang Depdikbud, 1994.

[6] Cormier \& Cormier, Interview Strategies for Helpers ( $3^{\text {rd }}$ Ed.), California: Brooks/Cole Publishing Company, 1991.

[7] Kemendikbud, Panduan Operasional Penyelenggaraan Bimbingan dan Konseling Sekolah Menengah Kejuruan (SMK), Jakarta: Kementrian Pendidikan dan Kebudayaan, 2016.

[8] A. Anastasi and S. Urbina, Tes Psikologi, Terjemahan Robertus Hariyono S. Imam, Jakarta: PT Indeks, 2007.

[9] W. Borg, and M. D. Gall, Educational Research: An Introduction $\left(4^{\text {th }}\right.$ Ed.), Boston: Pearson Education, Inc, 1983.

[10] S. Azwar, Penyusunan Skala Psikologis, Yogyakarta: Pustaka Pelajar Offset, 2003.

[11] I. Ghozali, Aplikasi Analisis Multivariate dengan Program SPSS, Semarang: Universitas Diponegoro, 2006.

[12] Joesmani, Pengukuran dan Evaluasi dalam Pembelajaran, Jakarta: Depdikbud, 1988.

[13] P.G. Mezo, The Self Control \& Self-Management Scale (SCMS): Development of an Adaptive Self-Regulatory Coping Skill Instrument. Psychopathol Behav Assess 2009, 31: 83-93.

[14] A.U. Syamnasti, Pengembangan Inventori Kontrol Diri untuk Siswa SMAN Negeri di Malang, Skripsi tidak diterbitkan, Malang: Universitas Negeri Malang. 2010.

[15] G. Xue \& X. Sun, Contruction and Validation of Self-Management Scale for Undergraduate Students. Scientific Research 2011, 2(2): 142147.

[16] S.T. Hasibuan, Gambaran Academic Self-Management pada Siswa Kelas Akselerasi SMP Harapan 2 dan SMP Al-Azhar Medan, Skripsi tidak diterbitkan, Medan: Universitas Sumatera Utara, 2015.

[17] I. F. Arrizal, Pengembangan Software Inventori Kontrol Diri bagi Siswa Sekolah Menengah Kejuruan, Skripsi tidak diterbitkan, Malang: Universitas Negeri Malang, 2016. 